\title{
Comparison of $1 \%$ cyclosporine eye drops in olive oil and in linseed oil to treat experimentally-induced keratoconjunctivitis sicca in rabbits
}

\author{
Comparação da ciclosporina 1\% em óleo de oliva e óleo de linhaça no tratamento da \\ ceratoconjuntivite seca experimentalmente induzida em coelhos
}

Leticia Rodrigues Parrilha ${ }^{1}$, Gisele Alborghetti Nal ${ }^{2}$, Rogério Giuffrida ${ }^{3}$, Rafael Cabral Barbero ${ }^{3}$, Leticia Dias Fabris Padovani ${ }^{3}$,

Ricardo Henrique Zaquir Pereira ${ }^{3}$, Danielle Alves Silva ${ }^{3}$, Mariele Catherine Alves Silva ${ }^{3}$, Miriely Stein Diniz ${ }^{3}$, Silvia Franco Andrade ${ }^{1}$

\begin{abstract}
Purpose: To evaluate the effectiveness of topical 1\% cyclosporine eye drops diluted in either of the two vehicles-olive and linseed oil-and that of the oils themselves in treating experimentally-induced keratoconjunctivitis sicca (KCS) in rabbits.

Methods: KCS was induced in 25 New Zealand rabbits using 1\% atropine sulfate eye drops for 7 days before treatment and throughout the treatment period (12 weeks). The rabbits were divided into five groups: one control (C) group withou KCS induction and four treatment groups in which KCS was induced and treated topically with olive oil (O), linseed oil (L), cyclosporine in olive oil (CO), and cyclosporine in linseed oil (CL). The animals were evaluated using Schirmer tear test 1 (STT), the fluorescein test (FT), tear-film break-up time (TBUT), the rose bengal test (RBT), and histopathological analysis.

Results: Values of STT and TBUT significantly decreased 1 week post-induction $(p<0.05)$ and were similar to initial values after the $4^{\text {th }}$ week of treatment, in all groups. After KCS induction, there was significantly less corneal damage in group L than in group $\mathrm{CL}$, as assessed FT and RBT. Histopathology demonstrated that Groups $L$ and $C L$ presented less edema and corneal congestion. There was no significant difference in the goblet cell density (cells $/ \mathrm{mm}^{2}$ ) between the groups ( $p=0.147$ ). Conclusion: Cyclosporine diluted in olive oil or linseed oil was effective in the treatment of KCS, although it had better efficacy when diluted in linseed oil. Linseed oil presented better effectiveness, whether associated or not, than olive oil. These results may contribute to the creation of novel topical ophthalmic formulations for KCS treatment in future.
\end{abstract}

Keywords: Cyclosporine/administration \& dosage; Olive oil; Linseed oil; Keratoconjunctivitis sicca; Rabbits

\section{RESUMO}

Objetivo: Avaliar a eficácia do uso tópico do colírio de ciclosporina 1\% em doisveículos, óleo de oliva e linhaça, e dos óleos separados, no tratamento da ceratoconjuntivite seca experimentalmente induzida (KCS) em coelhos.

Método: Vinte e cinco coelhos Nova Zelândia foram induzidos para KCS com colírio de sulfato de atropina a $1 \%$ por sete dias antes e durante o período de tratamento (12 semanas) e foram divididos em 5 grupos, um grupo controle (C), sem indução de KCS e quatro grupos de tratamento tópico com ciclosporina em óleo de oliva (CO), ciclosporina em óleo de linhaça $(C L)$, óleo de oliva $(O)$ e óleo de linhaça (L). Os animais foram avaliados utilizando o teste lacrimal de Schirmer I (STT), teste de fluoresceína $(F T)$, teste de ruptura do filme lacrimal (TBUT), teste de rosa bengala (RBT) e análise histopatológica.

Resultados: Os valores de TBUT E STT diminuíram significativamente uma semana pós-indução da KCS $(p<0,05)$ e foram semelhantes aos valores iniciais após a quarta semana de tratamento, em todos os grupos. Após a indução de KCS, houve menor dano na córnea no grupo $L$ em relação ao grupo $C L$, quando avaliados $F T$ e RBT. A histopatologia demonstrou que os grupos Le CL apresentaram menos edema e congestão da córnea. Não houve diferença significativa na densidade das células caliciformes (células $/ \mathrm{mm}^{2}$ ) entre os grupos $(p=0,147)$.

Conclusão: Ciclosporina diluída emóleo de oliva ou linhaça foieficiente no tratamento da CCS, porém teve uma melhor eficácia quando diluída no óleo de linhaça. O óleo de linhaça, isoladamente ou associado, apresentou melhor eficácia quando comparado ao óleo de oliva. Estes resultados podem contribuir no futuro com novas formulações oftálmicas tópicas no tratamento da CCS.

Descritores: Ciclosporina/administração \& dosagem; Óleo de palmeira; Óleo de semente do linho; Ceratoconjuntivite seca; Coelhos

\section{INTRODUCTION}

Keratoconjunctivitis sicca (KCS), or dry eye, is characterized by decreased tear quantity and/or quality. Clinical signs of KCS include ocular discomfort, dryness, irritation, foreign body sensation, light sensitivity, itching, and in severe cases, corneal ulceration, which can lead to blindness. Immune-mediated inflammation of the lacrimal glands is one of the most frequent causes of dry eye. The use of topical immunosuppressive drugs such as cyclosporine, tacrolimus, and pimecrolimus, alone or combined with artificial tears, are indicated; other agents, including corticosteroids, essential fatty acids, mucolytics, pilocarpine, and antibiotics, may be used as adjuvants or if the patient fails to respond to primary lacrimogenic therapy ${ }^{(1)}$.
Cyclosporine A ( $C S A)$, derived from the asexual ascomycete fungus Tolypocladium inflatum, is a noncytotoxic immunosuppressor that inhibits the proliferation of T lymphocytes by inhibiting interleukin-2 synthesis at the transcription level ${ }^{(2,3)}$. CsA use increases tear secretion and the number of goblet cells and decreases the incidence of corneal staining by interrupting the autoimmune anti-inflammatory reaction ${ }^{(1,4)}$. CsA eye drops are marketed in concentrations up to $0.05 \%$ in polivinilic alcohol, of $0.05 \%$ in an anionic ophthalmic emulsion (Restasis ${ }^{\circledR}$; Allergan, Irvine, CA, USA; glycerin base, castor oil, and polysorbate 80 ), of $1 \%$ and $2 \%$ in eye drops in an oily vehicle (olive oil), and of $0.2 \%$ in a veterinary ophthalmic ointment (Optimmune ${ }^{\circledR}$; Schering Plough, Summit, NJ, USA) $)^{(2,5-7)}$. Some adverse effects of ocular topical
Submitted for publication: November 26, 2014 Accepted for publication: June 1, 2015

Program in Animal Science, Universidade do Oeste Paulista, Presidente Prudente, SP, Brazil.

Department of Anatomy Pathology, Faculty of Medicine, Universidade do Oeste Paulista, Presidente Prudente, SP, Brazil.

${ }^{3}$ Faculty of Veterinary Medicine, Universidade do Oeste Paulista, Presidente Prudente, SP, Brazil.
Funding: No specific financial support was available for this study.

Disclosure of potential conflicts of interest: None of the authors have any potential conflicts of interest to disclose.

Corresponding author: Silvia Franco Andrade. Rodovia Raposo Tavares, km 572 - Presidente Prudente SP - 19067-175 - Brazil - E-mail: silviafranco@unoeste.br

Approved by the following research ethics committee: Ethics Committee on the Use of Animals (CEUA) of UNOESTE. Protocol number 720/11. 
CSA in humans include allergy, burning sensation, and irritation of the conjunctiva ${ }^{(6,7)}$.

Olive oil, from the fruit of the olive tree Olea europaea, contains a significant concentration of monounsaturated fatty acids (MUFAs), of which $70-80 \%$ are oleic acid, in addition to $10-15 \%$ saturated fatty acids (palmitic acid) and 5-10\% omega $3(\omega-3), 6(\omega-6)$, and $9(\omega-9)$ polyunsaturated fatty acids (PUFAs) $)^{(8)}$. Olive oil has been shown to possess antinociceptive, anti-inflammatory, antiarrhythmic, spasmolytic, immunostimulant, cardioprotective, hypotensive, hypoglycemic, and antimicrobial properties (9-11).

Linseed oil, from the flax plant Linum usitatissimum, is composed of $57 \% \omega-3,16 \% \omega-6,28 \%$ MUFA, and only $9 \%$ unsaturated fatty acids; the $\omega-3-$ to- $\omega-6$ ratio of 1:3 is considered to be close to ideal ${ }^{(12)}$. Linseed oil is given orally as an adjuvant therapy in patients with Sjögren's syndrome and $\mathrm{KCS}^{(13,14)}$. Some authors have reported the treatment of experimentally induced KCS in rabbits using linseed oil in various preparations (oral, topical, and oral/topical combination) ${ }^{(15,16)}$. In mice with experimentally induced KCS, the topical use of $\omega-3$ and $\omega-6$ has been shown to successfully control inflammatory symptoms ${ }^{(17)}$. Linseed oil is considered a natural anti-inflammatory agent due to its potential for synthesizing noninflammatory mediators, such as prostaglandin E1 (PGE1) and thromboxane A1 (TXA1)(18,19).

The objective of this study was to evaluate the effectiveness of cyclosporine, a potent immunosuppressor used in the treatment of KCS, as 1\% eye drops diluted in olive oil (already used as a vehicle for cyclosporine) or linseed oil, in addition to the use of each oil separately (without KCS), in the treatment of experimentally induced KCS in rabbits.

\section{METHODS}

\section{Animals}

This experiment was approved by the Ethics Committee on the Use of Animals of UNOESTE (protocol no 720/11). Twenty-five male New Zealand white rabbits (Oryctolagus cuniculus) of a mean age of 198 days and a mean weight of 3,600 g were selected from the Central Bioterium of UNOESTE and kept in individual metal cages with access to water and food ad libitum.

\section{THE INDUCTION OF KCS}

The induction model of KCS in rabbits was based on previously published studies that used $1 \%$ atropine sulfate eye drops three times daily ${ }^{(15,16,20-22)}$. Atropine is a competitive antagonist of the muscarinic acetylcholine receptors. As the ocular surface and main lacrimal gland are innervated by parasympathetic fibers of the seventh cranial nerve; the use of atropine is known to cause decreased tear secretion and consequent inflammation in a similar way to dry eye syndrome ${ }^{(20-22)}$. Eye drops were administered until the diagnosis of KCS (7 days to induce KCS in all rabbits) was confirmed by a Schirmer tear test 1 (STT; Teste de Schirmer ${ }^{\circledR}$; Ophthalmos Laboratory) result of $\leq 5 \mathrm{~mm} / \mathrm{min}$ and/or $\leq 10$ seconds tear-film break-up time (TBUT) ${ }^{(23,24)}$ and throughout the treatment period (12 weeks) for KCS maintenance.

\section{GROUPS}

The data from both eyes were pooled from the 25 rabbits. Of these rabbits, 20 were induced using the KCS protocol, and 5 were allocated to the non-induced control group. The timing of the $1 \%$ atropine eye drop instillation was 6:00 am, 2:00 pm, and 10:00 pm, and the timing of the treatment eye drop instillation was 8:00 am and 8:00 pm. Beginning 1 week after KCS induction, the animals were treated for 12 weeks as follows: Group C (control; n=5) (one drop of placebo, $0.9 \%$ $\mathrm{NaCl}$ solution [Fresenius Kabi, Campinas, São Paulo, Brazil], topically applied twice a day [BID] in both eyes); Group CO (one drop of 1\% cyclosporine in olive oil [Ophthalmos ${ }^{\circledR}$, São Paulo, Brazil], topically applied BID in both eyes); Group CL (one drop of 1\% cyclosporine in linseed oil [Ophthalmos ${ }^{\circledR}$ ], topically applied BID in both eyes); Group O (one drop of olive oil [Ophthalmos Laboratory], topically applied BID in both eyes); and Group L (one drop of linseed oil [Ophthalmos Laboratory], topically applied BID in both eyes). The rationale behind using 1\% CsA was that it is a manipulated concentration marketed by Ophthalmos Laboratory in Brazil.

\section{Ocular tests}

The following ocular tests were performed at time point T0 (before the induction of KCS), and at weeks 1 (T1), 2 (T2), 4 (T4), 8 (T8), and 12 (T12) post-induction, always in the morning (10:00 am). One blinded observer evaluated the ocular tests. All tests were performed concurrently.

STT was performed without anesthetic eye drops, and was used to determine the quantitative tear production.

TBUT for evaluation of the quality of the tears was performed twice, successively, and the mean was calculated. After placing a drop of $1 \%$ fluorescein eye drops (Fluoresceína ${ }^{\circledR}$; Allergan, São Paulo, Brazil) into the lower fornix, a slit-lamp, set on a bright light setting with a cobalt blue filter, was used to measure the time between the last blink and the first appearance of a dark spot on the cornea (formation of a dry area).

The fluorescein test (FT) was performed with 1\% fluorescein strips (Fluoresceína strips ${ }^{\circledR}$; Ophthalmos Laboratory) moistened with a small amount of normal saline to observe stained corneal epithelial irregularity in four quadrants (temporal superior, temporal inferior, nasal superior, and nasal inferior) and was scored 0 to 4 : (0) no staining; (1) one quadrant stained; (2) two quadrants stained; (3) three quadrants stained; and (4) four quadrants stained.

The rose bengal test (RBT) was performed to stain tissue devoid of mucus. Anesthetic eye drops ( $0.5 \%$ proxymetacaine, Anestalcon ${ }^{\circledR}$; Allergan, São Paulo, Brazil) were instilled followed by one drop of $0.5 \%$ rose bengal (Colírio de Rosa Bengala ${ }^{\circledR} ;$ Ophthalmos $\left.{ }^{\circledR}\right)$. The following scoring scale was used from 0 to 3 : (0) no staining; (1) only conjunctival staining; (2) only corneal staining; and (3) both conjunctival and corneal staining.

\section{Histopathological analysis}

For the histopathological analysis, the rabbits were euthanized at the end of the experiment (T12) using 2.5\% sodium thiopental (200 mg/kg) administered intravenously. After transpalpebral enucleation, the eyeball was placed in a 10\% formaldehyde solution for 24-48 hours. The eyes were stored in $70 \%$ alcohol, and then routinely processed and embedded in paraffin. Three serial sections of $5 \mu \mathrm{m}$ from the cornea and conjunctiva were obtained and stained with hematoxylin and eosin (HE) and periodic acid-Schiff (PAS). The cornea and conjunctiva were assessed for the following: edema, cellular degeneration, necrosis, inflammatory infiltrate (neutrophilic, mononuclear, and mixed), and goblet cell count (bulbar conjunctiva). Edema, cellular degeneration, and necrosis were scored from 0 to 3: (0) absence, (1) mild, (2) moderate, and (3) severe. Inflammatory infiltrate was scored from 0 to 3: (0) absent, (1) mild (1-4 cells per field), (2) moderate (5-9 cells per field), and (3) severe (>10 cells per field). Goblet cell density (cells $/ \mathrm{mm}^{2}$ ) was counted in five high-power fields (40x objective) on each slide, corresponding to an area of around $0.5 \mathrm{~mm}^{2}$. One blinded observer evaluated the histopathological exams.

\section{Statistical analysis}

The STT and TBUT values and goblet cell density were compared between the groups and time points using analysis of variance (ANOVA), in addition to Tukey's method. FT and RBT values, were analyzed with the Friedman and Kruskal-Wallis tests, for comparisons within groups over time and among different groups, respectively. A statistical significance level of $p<0.05$ was adopted. The software used for the statistical analysis was Biostat 5.3. 


\section{RESULTS}

Group C exhibited normal parameters throughout the entire experimental period. In the treatment groups, STT values at T1 were lower than those at T0 for group $O(3.7 \pm 1.3 ; p<0.01)$, group $L(4.1 \pm 1.6$; $p=0.01)$, group $C O(3.6 \pm 2.1 ; p<0.01)$, and group $C L(4.2 \pm 1.3 ; p=0.01)$. STT values increased in all treatment groups at T2, but were still lower than T0 in groups $O(5.4 \pm 1.0 ; p<0.01)$ and group $C L(6.4 \pm 2.4$; $p<0.01)$. There was no statistically significant difference at T4, T6, T8 and T12 in any of the groups in relation to T0 $(p>0.05)$ (Figure $1 \mathrm{~A}$ ) TBUT values decreased at T1 for group $O(3.8 \pm 1.4 ; p<0.01)$, group $L$ $(4.4 \pm 1.7 ; p<0.01)$, group CO $(4.9 \pm 0.7 ; p=0.01)$, and group CL (4.8 $\pm 1.7 ;$ $p=0.01)$. TBUT values increased at T2 in all treatment groups but were still lower than T0 in groups $O(13.3 \pm 3.9 ; p<0.01)$, CO $(12.6 \pm 3.3$; $p<0.01)$, and $C L(13.5 \pm 3.3 ; p<0.01)$. There was no statistically significant difference at T4, T6, T8 and T12 in all groups when compared to T0 ( $p>0.05)$ (Figure 1 B).

The FT results are presented in figure $2 \mathrm{~A}$. AtT1, only group $\mathrm{O}$ showed an FT score of 2 (two stained quadrants), while the other groups: L, $\mathrm{CO}$, and $\mathrm{CL}$, showed an FT score of 1 (one stained quadrant). At T2 and
T4, all treatment groups presented an FT score of 1, and at T8 and T12, no eyes showed positive staining. The RBT results are shown in figure $2 \mathrm{~B}$. From T1 to T4, all treatment groups presented a score of 2 (only corneal staining). At T8, groups $\mathrm{O}, \mathrm{L}$, and $\mathrm{CO}$ presented scores of 2 , and at T12, no eyes were RBT positive.

The histopathological images of the cornea and conjunctiva are presented in figure 3. A normal cornea from group $C$ is shown in figure 3 A. Slight edema and conjunctival congestion were found in groups $\mathrm{O}$ (Figure 3 B) and CO. Regarding the goblet cell density (Figures $3 \mathrm{C}$ and D), there was no statistically significant difference between the groups ( $p=0.147$ ), although group $C L$ appeared to have higher values $(11.2 \pm 3.5)$ compared to groups C $(8.0 \pm 2.1), \mathrm{O}(7.6 \pm 3.7), \mathrm{L}(9.0 \pm 3.4)$, and $\mathrm{CO}(8.4 \pm 3.2)$. The histopathological results of all the conjunctival samples from group CO (Figure $3 \mathrm{E}$ ) and $\mathrm{O}$ (Figure $3 \mathrm{~F}$ ) showed more chronic inflammation than the other treatment groups.

\section{DISCUSSION}

When comparing the two different oils, linseed oil showed a more favorable and rapid effect than olive oil in terms of the STT and TBUT
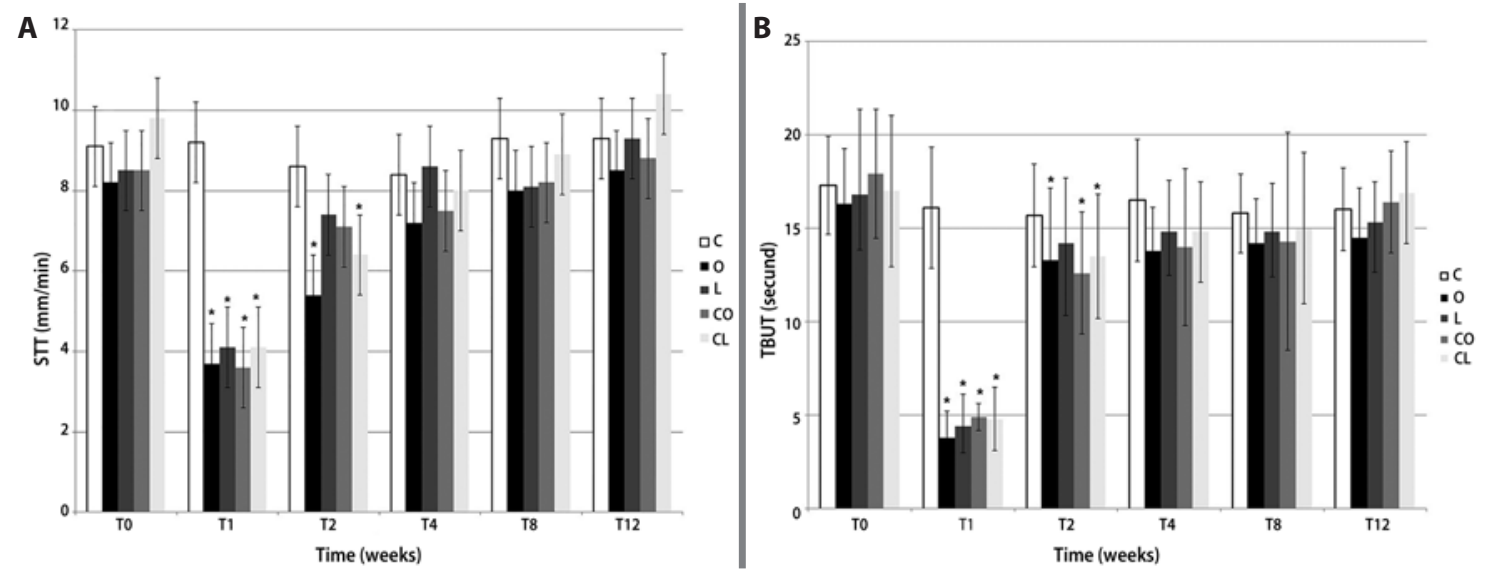

${ }^{*} P<0.05$ (Tukey's test, compared to control group).

Figure 1. Mean \pm SD for (A) Schirmer's tear test I (STT I) ${ }^{\mathrm{a}}$ in $\mathrm{mm} / \mathrm{min}$ and (B) tear-film break-up time (TBUT) ${ }^{\mathrm{b}}$ in seconds, in rabbits with experimentally induced keratoconjunctivitis sicca (KCS) that were treated with various topical formulations: placebo (group C), olive oil (group O), linseed oil (group L), $1 \%$ cyclosporine in olive oil (group CO), and 1\% cyclosporine in linseed oil (group CL).
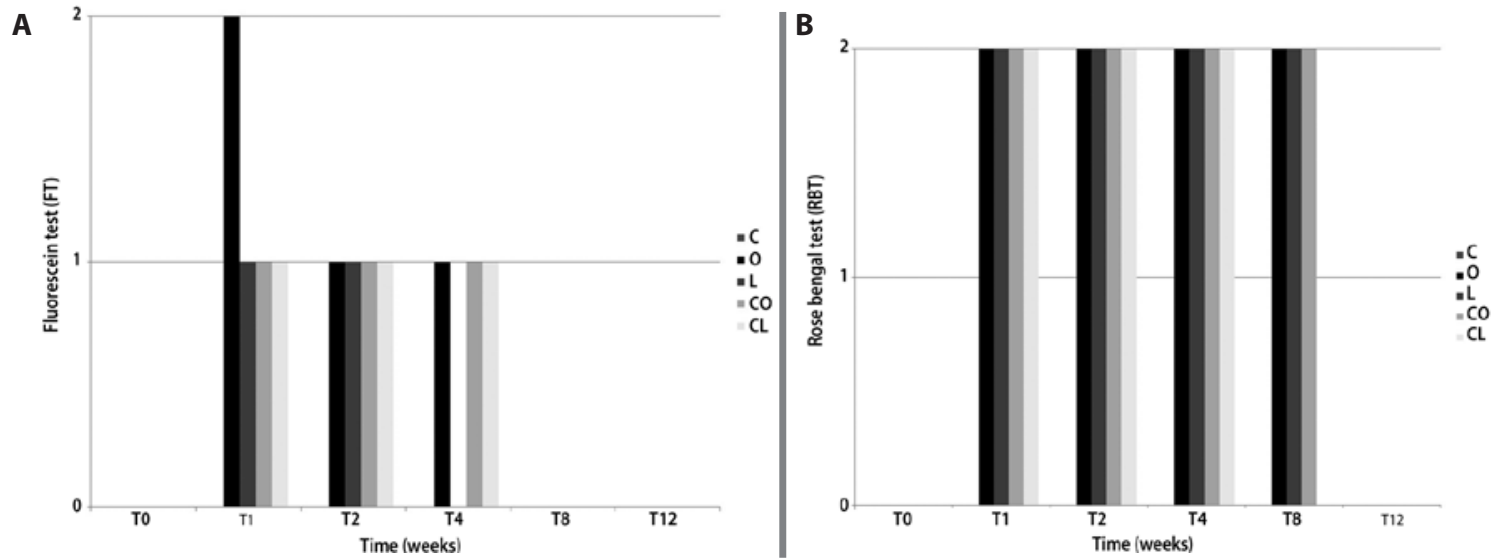

$=(0)$ no staining, (1) one quadrant stained, (2) two quadrants stained.

$b=(0)$ no staining, (1) only conjunctival staining, (2) only corneal staining, (3) conjunctival and corneal staining

Figure 2. Median results for $(A)$ fluorescein test $(F T)^{\mathrm{a}}$ and $(\mathrm{B})$ rose bengal test $(\mathrm{RBT})^{\mathrm{b}}$ in rabbits with experimentally induced keratoconjunctivitis sicca (KCS) that were treated with various topical formulations: placebo (group C), olive oil (group O), linseed oil (group L), $1 \%$ cyclosporine in olive oil (group $\mathrm{CO}$ ), and $1 \%$ cyclosporine in linseed oil (group $\mathrm{CL}$ ). 

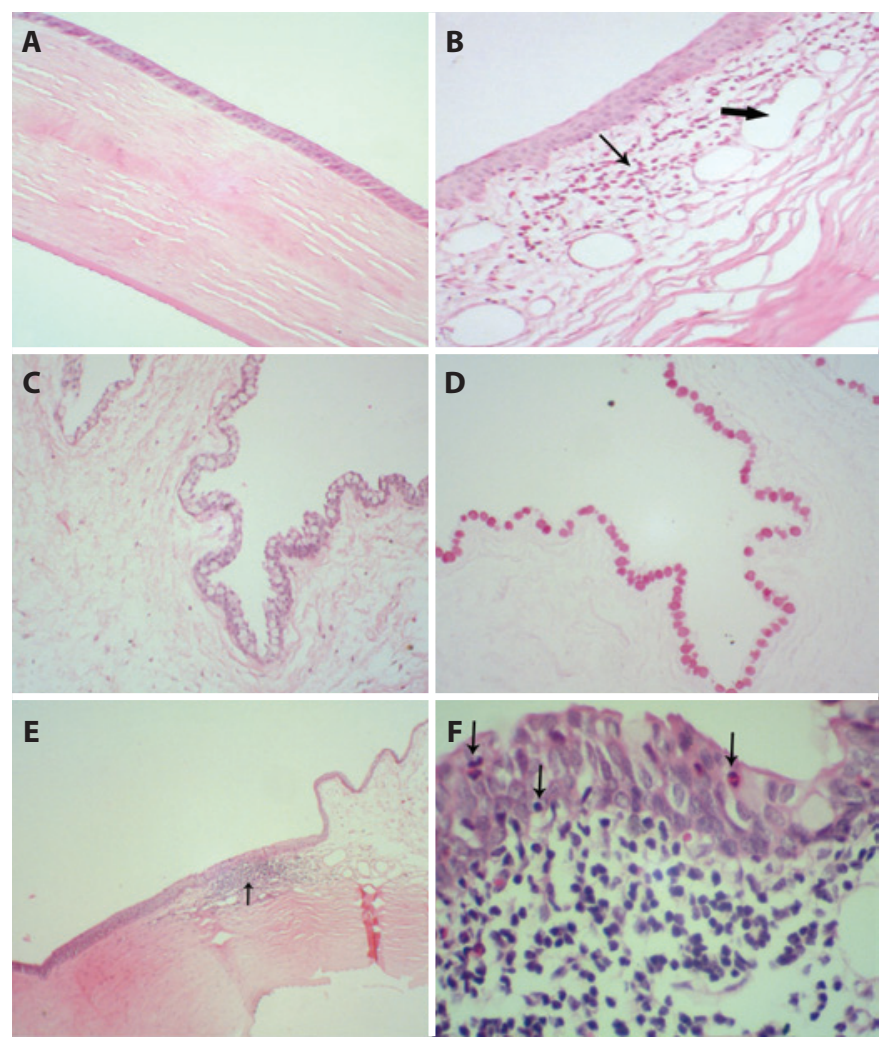

Figure 3. Photomicrographs of the cornea and conjunctiva atT12. (A) Normal cornea from group C (control) (hematoxylin and eosin [H\&E]; 100x). (B) Conjunctiva with eosinophil infiltration (thin arrow), edema, and vascular congestion (capillary dilatation-large arrows) in group $\mathrm{O}$ (olive oil) ( $\mathrm{H \& E} ; 100 \times)$. (C) Conjunctiva with a large number of goblet cells in group CL (1\% cyclosporine in linseed oil) (H\&E; 100x). (D) Goblet cells from group CL (1\% cyclosporine in linseed oil) (periodic acid-Schiff [PAS]; 100×). (E) Focal chronic inflammatory process in the transition from the conjunctiva to the cornea (arrow) in group CO (1\% cyclosporine in olive oil) (H\&E; 40X). (F) Details of the chronic inflammation in the conjunctiva with aggression of the epithelium (presence of inflammatory cells within the epithelium) (arrows) in group O (olive oil) (H\&E; 400X).

results at T2, FT results at T4, and in the histopathological results. In general, Group O showed the worst results in the treatment of KCS. These variations could be explained by the difference in composition for each oil. Olive oil contains a larger quantity of MUFA (70-80\% oleic acid) and only a small amount of PUFA (5-10\% of $\omega-3, \omega-6$, and $\omega-9)^{(10,11)}$. Linseed oil is comprised of $16 \% \omega-6$ and $57 \% \omega-3$, which are natural anti-inflammatory agents due to their ability to synthesize noninflammatory mediators ${ }^{(12,25)}$. The $\omega-6$ origin of PGE1 and TXA1 via cyclooxygenase $1(C O X 1)$ and the effects of the $\omega$-3 fatty acids eicosapentaenoic acid and docosapentaenoic acid could explain the clinical improvements in the animals that received the linseed oil treatment ${ }^{(18,19)}$.

These results are in agreement with a previous study that used a topical formulation containing an emulsion of alpha-linolenic acid and linoleic acid on mice with experimentally induced KCS; the inflammatory symptoms of KCS improved in the mice ${ }^{(17)}$. A recent study compared almond and linseed oil as diluents of tacrolimus, another immunosuppressor, in the treatment of KCS in rabbits and showed that linseed oil either as a diluent or in isolation was more effective than almond oil ${ }^{(16)}$. Another study evaluated the effectiveness of various linseed oil preparations (oral, topical, and an oral/topical combination) in treating experimentally induced KCS in rabbits, and concluded that orally or topically administered linseed oil was effective in the treatment of KCS, although the combined oral/topical treatment did not show additional benefits ${ }^{(15)}$.
When the CsA groups were compared with the oil groups, groups $\mathrm{CL}$ and $\mathrm{CO}$ were found to present similar TBUT and FT results at the end of the experiment. Additionally, there was more rapid negative RBT staining for group $C L$, which also had higher, although non-statistically significant, goblet cell density. The better results in group CL for these parameters might be due to the combination of the anti-inflammatory properties of the linseed oil and the immunosuppressive effects of the cyclosporine. This result is in agreement with the findings from the study that used tacrolimus, another immunosuppressor used in KCS treatment; the group that was administered tacrolimus diluted with linseed oil showed better improvement in KCS control in rabbits, with increased goblet cell density in the conjunctiva ${ }^{(16)}$. In rabbits with KCS induced by autoimmune dacryoadenitis, the use of $0.05 \%$ CsA in an ophthalmic emulsion (Restasis ${ }^{\circledR}$ ) promoted significantly increased tear production ${ }^{(26)}$. These CsA effects are due to the immunosuppressive action that minimizes the inflammatory damage induced by KCS in the cornea, conjunctiva, and goblet cells ${ }^{(2-5)}$. The increased density of goblet cells in KCS is very important because decreased goblet cell density can induce mucin deficiency in the precorneal tear film and may result in ulcerated corneas with irregular surfaces ${ }^{(4,27)}$.

The histopathological results also demonstrate a stronger inflammatory process in the $\mathrm{O}$ and $\mathrm{CO}$ groups (Figures $4 \mathrm{E}$ and $\mathrm{F}$ ), as assessed by the presence of mild edema in the cornea and moderate edema and congestion in the conjunctiva. Additionally, only group $\mathrm{O}$ demonstrated squamous metaplasia, which was most likely due to chronic ocular inflammation ${ }^{(1,2,5)}$. The goblet cell density was not significantly increased in group CL when compared to the other groups, but this difference could potentially become statistically significant in a larger population.

We conclude that cyclosporine diluted in olive oil and linseed oil is effective for the treatment of experimentally induced KCS in rabbits. However, linseed oil, when used alone or as a diluent for cyclosporine, is more effective at treating KCS than olive oil. This study reveals that both the immunosuppressive effect of cyclosporine and the properties of the oil medium, particularly the anti-inflammatory properties of linseed oil, are responsible for the improvement of dry eye symptoms in rabbits. These results may contribute to the development of novel topical ophthalmic formulations for the treatment of KCS in future.

\section{ACKNOWLEDGMENTS}

We would like to thank the Post-Graduate Program in Animal Science of Universidade do Oeste Paulista, Presidente Prudente (SP), Brazil, for the financial support and the Laboratory Ophthalmos ${ }^{\circledR}$ for the donation of some of the materials necessary for the execution of the experiment.

\section{REFERENCES}

1. Stevenson W, Chauhan SK, Dana R. Dry eye disease: an immune-mediated ocular surface disorder. Arch Ophthalmol. 2012:130(1):90-100.

2. Benitez del Castillo JM, Del Aguila C, Duran S, Hernandez J, García Sánchez J. Influence of topically applied cyclosporine A in olive oil on corneal epithelium permeability. Cornea. 1994;13(2):136-40.

3. Izci C, Celik I, Alkan F, Ogurtan Z, Ceylan C, Sur E, et al. Histologic characteristics and local cellular immunity of the gland of the third eyelid after topical ophthalmic administration of $2 \%$ cyclosporine for treatment of dogs with keratoconjunctivitis sicca. Am J Vet Res. 2002;63(5):688-94.

4. Kunert KS, Tisdale, AS, Gipson IK. Goblet cell numbers and epithelial proliferation in the conjunctiva of patients with dry eye syndrome treated with cyclosporine. Arch Ophthalmol. 2002;120(3):330-7.

5. Yavuz B, Pehlivan SB, Ünlü N. An overview on dry eye treatment: approaches for cyclosporine A delivery. ScientificWorldJournal. 2012;2012:194848.

6. Liang H, Baudouin C, Daull P, Garrigue JS, Brignole-Baudouin F. Ocular safety of cationic emulsion of cyclosporine in an in vitro corneal wound-healing model and an acute in vivo rabbit model. Mol Vis. 2012;18:2195-204.

7. Utine CA, Stern M, Akpek EK. Clinical review: topical ophthalmic use of cyclosporin A. Ocul Immunol Inflamm. 2010;18(5):352-61. 
8. Waterman E, Lockwood B. Active components and clinical applications of olive oil. Alt Med Rev. 2007;12(4):331-42.

9. Al-Azzawie HF, Alhamdanim SS. Hypoglycemic and antioxidant effects of oleuropein in alloxan-diabetic rabbits. Life Sci. 2006;78(12):1371-7.

10. Wardhana EE, Surachmanto EAD. The role of omega-3 fatty acids contained in olive oil on chronic inflammation. Acta Medica Indon. 2011;43(2):138-42.

11. Eidi A, Moghadam-Kia S, Moghadam JZ, Eidi M, Rezazadeh S. Antinociceptive and anti-inflammatory effects of olive oil (Olea europeae L.) in mice. Pharmac Biol. 2012 50(3):332-7.

12. Oomah BD. Flaxseed as functional source. J Sci Food Agric. 2001;81:889-94.

13. Roncone $M$, Bartlett $H$, Eperjesi, F. Essential fatty acids for dry eye: A review. Contact Lens \& Anterior Eye. 2010;33(2):49-54

14. Wojtowicz JC, Butovich I, Uchiyama E, Aronowicz J, Agee S, McCulley JP. Pilot, prospective, randomized, double-masked, placebo-controlled clinical trial of an omega-3 supplement for dry eye. Cornea. 2011;30(3):308-14.

15. Neves ML, Yamasaki L, Sanches OC, et al. Use of linseed oil to treat experimentally induced keratoconjunctivitis sicca in rabbits. J Ophthalmic Inflamm Infection. 2013;3:4:1-5.

16. Sgrignoli MR, Yamasaki L, Sanches OC, do Amaral MS, Stevanin H, Giuffrida R, et al Comparison of topical $0.03 \%$ tacrolimus in almond and linseed oil to treat experimentally induced keratoconjunctivitis sicca in rabbits. Int J Ophthalmic Pathol. 2013; 3(1):4.

17. Rashid S, Jin Y, Ecoiffer T, Barabino S, Schaumberg DA, Dana MR. Topical omega-3 and omega-6 fatty acids for treatment of dry eye. Arch Ophthalmol. 2008;126(2):210-25.

18. Barabino S, Rolando M, Camicione P, Ravera G, Zanardi S, Giuffrida S, et al. Systemic linoleic and g-linolenic acid therapy in dry eye syndrome with an inflammatory component. Cornea. 2003;22(2):97-101.
19. Aragona P, Bucolo C, Spinella R, Giuffrida S, Ferreri G. Systemic omega-6 essential fatty acid treatment and pge 1 tear content in Sjögren's syndrome patients. Invest Ophthalmol Vis Sci. 205;46(12):4474-9.

20. Burgalassi S, Panichi L, Chetoni, PE, Saettone MF, Boldrini E. Development of a simple dry eye model in the albino rabbit and evaluation of some tear substitutes. Ophthalmol Res. 1999:31(3):229-35.

21. El-Shazly AH, El-Gohrary AH, El-Shazly LH, El-Hossary GG. Comparison between two ciclooxigenase inhibitors in an experimental dry eye model in albino rabbits. Acta Pharmaceutica. 2008:58(2):163-73.

22. Shafaa MW, El Shazly LH, AH. El Shazly AH, El Gohary AA, El Hossary GG. Efficacy of topically applied liposome-bound tetracycline in the treatment of dry eye model. Vet Ophthalmol. 2011:14(1):18-25.

23. Holmberg JB. Opthalmology of exotic pets. In: Slatter's Fundamentals of Veterinary Ophthalmology, $5^{\text {th }}$ edn. (eds Maggs DJ, Miller PE, Ofri R) Saunders Elsevier, St. Louis; 2013. p.427-41

24. Wei XE, Markoulli M, Zhao Z, Willcox MD. Tear film break-up time in rabbits. Clin Exp Optom. 2013;96(1):70-5

25. Hassan-Zadeh A, Sahari MA, Barzegar M. Optimization of the omega-3 extraction as a functional food from flaxseed. Int J Food Scienc Nutrit. 2008;59(6):526-34.

26. Thomas PB, Samant DM, Zhu Z, Selvam S, Stevenson D, Wang Y, et al. Long-term topical cyclosporine treatment improves tear production and reduces keratoconjunctivitis in rabbits with induced autoimmune dacryoadenitis. J Ocular Pharmacol Therap. 2009;25(3):285-91.

27. Davidson HJ, Kuonen VJ. The tear film and ocular mucins. Vet Ophthalmol. 2004;7(2): 71-7.

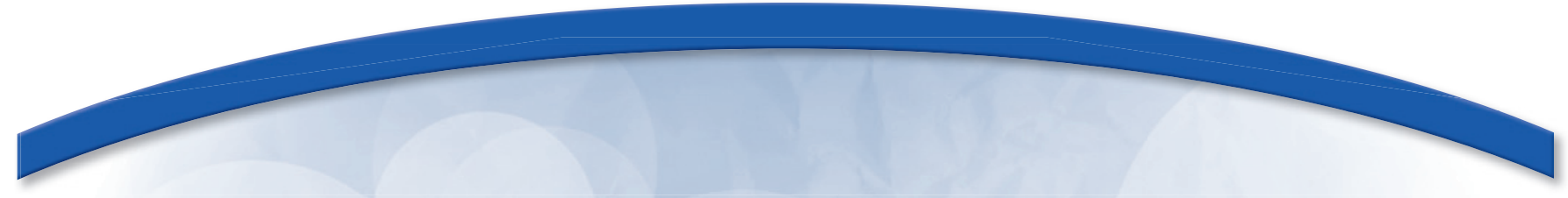

XXXV Congresso do Hospital São Geraldo

\section{9 a 31 de outubro de 2015}

Hotel Mercure Lourdes

Belo Horizonte - MG

\section{Informações:}

Tel.: (31) 3342-3888

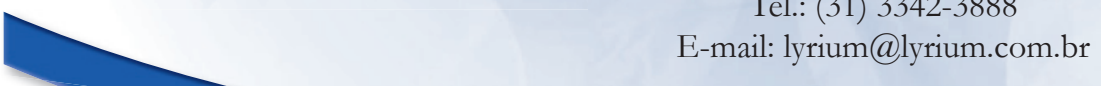

